\title{
Pemberdayaan masyarakat dalam meningkatkan produktivitas sapi pesisir di Nagari Taratak - Sutera Kabupaten Pesisir Selatan
}

\author{
Montesqrit*, Arfai, \& Rusdimansyah \\ Universitas Andalas \\ * montesqrit@ansci.unand.ac.id
}

\begin{abstract}
Abstrak. Sapi Pesisir merupakan sapi lokal Sumatera Barat yang mempunyai keunggulan tahan terhadap penyakit dan dapat bertahan hidup dengan mengkonsumsi makanan yang tidak unggul. Kecamatan Sutera adalah salah satu sentra peternakan sapi pesisir di Kabupaten Pesisir Selatan Sumatera Barat. Keberadaan sapi pesisir ini mulai menurun karena banyaknya betina bunting yang dipotong serta banyaknya peternak yang meninggalkan usaha beternak sapi ini. Salah satu penyebabnya adalah pemelihaharaan sapi yang tidak efektif dengan pola makan yang tidak bagus mengakibatkan performa dan produktivitasnya rendah padahal kalau ditingkatkan manajemen pemeliharaannya seperti disediakan ransum yang baik tentu produktivitas sapi tersebut dapat ditingkatkan. Berdasarkan hal tersebut perlu dilakukan pemberdayaan pada masyarakat untuk memelihara ternak dengan menyediakan ransum yang dapat memenuhi kebutuhan sehingga produktivitas sapi dapat ditingkatkan. Tujuan dari KKN-PPM tematik ini adalah diharapkan mahasiswa mampu memotivasi dan memberdayakan masyarakat disana. Metode yang digunakan dalam pencapaian tersebut adalah metode penyuluhan dan dilanjutkan dengan demonstrasi dan terjun langsung ke lapangan. Kegiatan yang dilakukan adalah alih teknologi dalam penyediaan ransum untuk sapi pesisir, membuat formulasi ransum sapi pesisir sesuai kebutuhan. Hasil yang didapatkan terbukanya wawasan masyarakat untuk memelihara ternak dengan semi intensif dengan cara dikandangkan dan ransumnya disediakan sesuai dengan formulasi ransum sapi pesisir yang dibuat. Ransum yang disediakan untuk sapi pesisir adalah dalam bentuk silase ransum komplit dengan memanfaatkan sumber bahan baku pakan yang banyak tersedia disana yaitu rumput lapang, jerami padi, dedak padi dan sumber pakan lainnya. Dengan silase ransum komplit tersebut membantu peternak lebih efektif dalam penyediaan ransum dan dapat meningkatkan produktivitas sapi pesisir.
\end{abstract}

Kata kunci: formulasi ransum; jerami padi; sapi pesisir; silase ransum komplit

\begin{abstract}
Pesisir cattle are local West Sumatra cattle that have the advantage of being resistant to disease and can survive by consuming foods that are not superior. Sutera Subdistrict is one of the centers of pesisir cattle farms in Pesisir Selatan District, West Sumatra. The existence of these pesisir cows began to decline because of the large number of pregnant females being cut and the number of breeders who left this cattle breeding business. One reason is that ineffective cattle maintenance with poor diet results in low performance and productivity, even if improved maintenance management such as good ration is provided, the productivity of the cow can be increased. Based on this, it is necessary to empower the community to raise livestock by providing rations that can meet the needs so that the productivity of cattle can be increased. The aim of this thematic KKN-PPM is how students are able to motivate and empower the community there. The method used in this achievement was the extension method and continued with demonstrations and going directly to the field. The activity carried out was technology transfer in the provision of rations for pesisir cattle, making a formulation of pesisir cattle rations as needed. The results obtained open the public's insight to maintain semi-intensive livestock by means of being grounded and their rations provided in accordance with the formulation of pesisir cattle rations made. The ration provided for pesisir cattle is in the form of a complete silage ration by utilizing a source of feed raw materials that are widely available there namely field grass, rice straw, rice bran and other feed sources. With complete silage, the ration helps farmers to be more effective in providing rations and can increase the productivity of pesisir cattle.
\end{abstract}

Keywords: complete ration silage; pesisir cattle; ration formulation 
To cite this article: Montesqrit, Arfai, \& Rusdimansyah. 2019. Pemberdayaan masyarakat dalam meningkatkan produktivitas sapi pesisir di Nagari Taratak - Sutera Kabupaten Pesisir Selatan. Unri Conference Series: Community Engagement 1: 518-526 https://doi.org/10.31258/unricsce.1.518-526

(C) 2019 Authors

Peer-review under responsibility of the organizing committee of Seminar Nasional Pemberdayaan Masyarakat 2019

\section{PENDAHULUAN}

Lokasi pelaksanaan KKN-PPM tematik ini adalah Nagari Taratak di Kecamatan Sutera Kabupaten Pesisir Selatan. Nagari tersebut berjarak lebih kurang 45 km dari ibu kota Kabupaten Pesisir Selatan yaitu Painan dan sekitar $123 \mathrm{Km}$ dari Kota Padang. Nagari Taratak berbatasan sebelah Utara dengan nagari taluak kecamatan batang kapas, sebelah Barat dengan samudra Indonesia, sebelah Timur dengan nagari Surantih dan koto taratak dan sebelah selatan dengan lansano taratak. Nagari taratak sebelumnya terdiri atas 6 Jorong/kampung akan tetapi sejak tahun 2011 tinggal 2 jorong karena 4 jorong sudah dimekarkan menjadi 2 nagari baru yaitu nagari lansano taratak dan koto taratak yang masing- masing mempunyai 2 jorong. Dua jorong yang tersisa di nagari taratak yaitu jorong pasar taratak dan jorong air terjun.

Mata pencaharian utama masyarakat nagari taratak adalah nelayan, beternak dan sedikit yang bertani akan tetapi masih banyak lahan kosong yang jauh dari pantai belum termanfaatkan dengan baik. Tingkat perekonomian masyarakat masih rendah dimana ada sekitar 15\% KK miskin sehingga menyebabkan nagari ini termasuk dalam salah satu nagari rawan pangan di Kab Pesisir Selatan dan provinsi Sumatera Barat.

Potensi ternak di nagari ini sebelumnya adalah banyak didapatkan ternak sapi lokal yaitu sapi pesisir. Sapi pesisir merupakan sapi asli Sumatera Barat dengan keunggulannya tahan terhadap penyakit dan dapat bertahan hidup walaupun mengkonsumsi makanan yang kurang dan rendah gizi. Kekurangan dari sapi ini adalah performanya yang rendah dibanding sapi lokal Indonesia lainnya seperti sapi bali ataupun sapi madura.

Kecamatan Sutera adalah salah satu sentra peternakan sapi pesisir di Kabupaten Pesisir Selatan Sumatera Barat selain itu sapi sapi tersebut banyak juga ditemukan di kecamatan ranah pesisir dan kecamatan pancung soal serta daerah lainnya di Sumatera Barat dalam jumlah kecil. Keberadaan sapi pesisir ini mulai menurun karena banyaknya betina bunting yang dipotong serta banyaknya peternak yang meninggalkan usaha beternak sapi ini, salah satu penyebabnya adalah dalam pemelihaharaan sapi yang tidak efektif.

Sapi pesisir tersebut jarang dikandangkan dan banyak dari sapi tersebut dilepas ke jalan-jalan dengan mengkonsumsi makanan yang kurang layak dan kurang dari kebutuhannya serta juga membuat pemandangan yang tidak sehat dengan berkeliarannya sapi tersebut dijalan-jalan. Akibat dari pola makan yang tidak bagus mengakibatkan performa dan produktivitasnya rendah padahal kalau ditingkatkan manajemen pemeliharaannya seperti disediakan ransum yang baik tentu produktivitas sapi tersebut dapat ditingkatkan.

Nagari taratak banyak terdapat ternak sapi lokal yaitu sapi pesisir akan tetapi pemeliharaannya yang tidak efektif sehingga ternak tersebut belum dikandangkan dan makanan yang dikonsumsi belum memenuhi kebutuhan gizinya. Berdasarkan hal tersebut diatas perlu dikembangkan berbagai transfer teknologi untuk memberdayakan masyarakat sehingga dapat meningkatkan pendapatan masyarakat. Dengan kondisi permasalahan tersebut adanya program KKN PPM ini yaitu meningkatkan usaha peternakan sapi lokal dengan dikandangkan dan penyusunan formula sapi yang sesuai dengan kebutuhan, pemanfaatan dan pengolahan pakan yang banyak tersedia dilapangan.

Kawasan perdesaan budidaya sapi salah satunya terletak di nagari taratak kecamatan sutera (Helmiati dkk, 2016). Jumlah peternak pemelihara sapi pesisir didaerah Pesisir Selatan mencapai 33 ribu kepala keluarga (Dipertahorbunnak Pesisir Selatan 2012). Hasil penelitian membuktikan penerapan dan pengembangan teknologi berperan penting dalam meningkatkan produksi sapi dengan pemeliharaan tradisional (Bamualim dan wirdahayati 2006). Menurut Wahyuni dan Dewi (2018) teknologi tepat guna yang dapat diterapkan untuk memperbaiki pola pemeliharaan sapi pesisir salah satunya adalah teknologi pakan dengan memanfaatkan limbah tanaman dengan cara amoniasi, dan silase dari tanaman yang ada.

Tema utama yang akan dilaksanakan oleh mahasiswa KKN tematik selama mereka berada di lokasi KKN adalah: (i) penyusunan formulasi ransum sapi pesisir dengan bahan baku yang ada di lokasi KKN-PPM, (ii) penyuluhan dan demonstrasi pengawetan pakan dalam bentuk silase, (iii) pengolahan jerami padi dengan cara amoniasi serta (iv) penanaman bibit hijauan unggul. 
Tujuan dari kegiatan pengabdian ini adalah memotivasi dan memberdayakan masyarakat Nagari Taratak Kecamatan Sutera kabupaten Pesisir Selatan dengan melibatkan mahasiswa KKN-PPM guna mentransfer ilmu pengetahuan dan teknologi agar produktivitas usaha beternak sapi pesisir meningkat.

\section{MASALAH}

Masalah yang dihadapi adalah berkurangnya animo dan perhatian masyarakat untuk memelihara sapi pesisir, hal ini disebabkan karena produktivitas sapi yang kurang baik dan tergodanya dengan sapi bukan pesisir, serta metode pemeliharaan yang kurang tepat menyebabkan berkurangnya populasi sapi pesisir. Selain itu yang paling banyak penyebabnya adalah masalah penanganan pakan.

Pakannya masih kurang dari kebutuhan ternak, apalagi sapi tidak dikandangkan dan ternak dilepas keluar yang mana pakan tidak ada tersedia karena sudah dijadikan sawah atau rumah akibatnya sapi kurang makan dan tidak sesuai dengan kebutuhan sapi tersebut. Jerami padi banyak disawah akan tetapi masyarakat tersebut belum mengetahui pengolahan jerami padi sehingga jerami padi tersebut dapat diberikan ke ternak dan kecernaannya juga meningkat.

Begitu juga ketersediaan rumput lapang sebagai pakan utama saat ternak dilepas, pada musim penghujan jumlahnya banyak akan tetapi pada musim kemarau rumput tersebut mengering dan ternak tidak mau mengkonsumsi, padahal kalau dijadikan silase maka rumput tersebut masih dapat digunakan pada musim kemarau. Pengetahuan ini belum diketahui oleh peternak di nagari taratak.

Untuk mengatasi berkurangnya animo dan perhatian masyarakat untuk menjaga kemurnian sapi lokal yang ada dilokasi KKN yaitu sapi pesisir yaitu dengan memberikan penyuluhan dan demonstrasi agar peternak memperbaiki sistem beternaknya. Solusi yang ingin ditawarkan adalah 1) Penyusunan ransum yang sesuai untuk sapi pesisir, 2) pengawetan hijauan dengan silase, 3) pengolahan jerami padi dengan cara amoniasi.

Penyusunan ransum untuk sapi pesisir dilakukan dengan memanfaatkan bahan pakan yang banyak tersedia di lokasi KKN. Ransum disusun sesuai dengan kebutuhan ternak tersebut sehingga diharapkan ternak yang dipelihara dapat meningkat produktivitasnya. Untuk menjaga supaya ransum tersedia setiap saat walaupun di musim kemarau maka diberikan penyuluhan dan demonstrasi pembuatan silase hijauan ataupun silase ransum komplit, dengan teknologi ini diharapkan peternak terbantu dalam penyediaan ransum.

Limbah pertanian yang banyak tersedia dan terbuang disana seperti jerami padi dimanfaatkan sebagai bahan pakan yang bernilai tinggi dengan mengolahnya dengan amoniasi atau fermentasi sebelum diberikan ke ternak.

Berdasarkan hal tersebut Kuliah Kerja Nyata yang merupakan program Pembelajaran Pemberdayaan Masyarakat yang bersifat Tematik (KKN-PPM Tematik) sangat relevan diadakan di Nagari tersebut. KKNPPM Tematik Unand di nagari Taratak untuk tahun 2019 ini diharapkan dapat mengarahkan cara pandang masyarakat untuk lebih mengoptimalkan potensi-potensi nagari yang ada sehingga prediket sebagai nagari rawan pangan dapat diwujudkan menjadi nagari mandiri pangan dimana kebutuhan pangan dapat didapat di daerah tersebut.

Target luaran dari kegiatan KKN-PPM ini adalah didapatkannya produk masyarakat disana dengan transfer iptek yang diberikan oleh mahasiswa KKN dan tim pengusul kkn-ppm. Diharapkan akan muncul produkproduk masyarakat disana diantaranya silase ransum komplit yang dapat digunakan untuk ternak mereka sendiri ataupun untuk peternak disekitar lokasi KKN ini.

\section{METODE}

Waktu pelaksanaan pengabdian ini selama 5 bulan dimulai sejak pertengahan Februari 2019 sampai dengan pertengahan Juli 2019. Pengabdian diawali dengan memberikan pembekalan kepada mahasiwa-mahasiswa yang ikut dalam program KKN Tematik Hibah Dikti. Pembekalan yang diberikan terkait dengan programprogram iptek untuk memberdayakan masyarakat di Taratak Kecamatan Sutera Kabupaten Pesisir Selatan.

Tahapan atau langkah-langkah dalam melaksanakan solusi yang ditawarkan untuk mengatasi permasalahan yang dihadapi masyarakat di Nagari Taratak Kecamatan Sutera Kabupaten Pesisir adalah menempatkan mahasiswa kkn tematik dilokasi tersebut. Sebelum mereka ke lapangan mereka diberi pembekalan terhadap program kerja yang merupakan tematik. Dengan adanya mahasiswa tersebut dapat mentransfer iptek dari perguruan tinggi kepada masyarakat nagari Taratak. 


\section{Persiapan dan Pembekalan}

Materi Persiapan dan pembekalan KKN-PPM yang perlu diberikan kepada mahasiswa, yakni: (i) materi persiapan, meliputi pengetahuan dan keterampilan teknis tentang program KKN tematik yang akan dilaksanakan dan (ii) materi pembekalan. Pembekalan dilaksanakan yaitu Pembekalan Khusus Tematik meliputi semua program KKN-PPM tematik yang akan dilaksanakan yaitu: (i) penyusunan formulasi ransum sapi pesisir dengan bahan baku yang ada di lokasi (ii) pengawetan hijauan dalam bentuk silase (iii) pengolahan jerami padi dengan amoniasi serta (iv) penanaman hijauan unggul.

\section{Pelaksanaan}

Program yang akan dilaksanakan untuk mencapai hasil yang diharapkan dari KKN-PPM ini meliputi program utama dan program penunjang. Program utama yang akan dilaksanakan adalah:

1. penyusunan formulasi ransum sapi pesisir dengan bahan baku yang ada di lokasi KKN-PPM, dalam penyuluhan ini mahasiswa akan didampingi oleh pembimbing, dimana sebelumnya mahasiswa ditugaskan untuk mengidentifikasi bahan pakan yang ada disekitar lokasi KKN, selanjutnya Dosen pembimbing bersama dengan mahasiswa dari Fakultas Peternakan akan menyusun formulasi ransum yang sesuai dengan umur, jenis kelamin dari ternak sapi pesisir

2. penyuluhan dan demonstrasi pengawetan pakan dalam bentuk silase, silase yang akan dibuat berdasarkan hijauan yang ada disana dan juga silase ransum komplit yang mengandung bahan pakan yang sudah lengkap yang sesuai dengan formulasi ransum yang telah dibuat

3. pengolahan limbah pertanian yang ada disana yaitu jerami padi yang diolah deng an cara amoniasi.

4. penanaman bibit hijauan unggul yaitu bibit rumput gajah yang diambil dari UPT Fakultas Peternakan Universitas Andalas.

\section{Langkah-langkah Operasional}

Langkah-langkah operasional yang perlu dilakukan untuk mengatasi permasalahan adalah sebagai berikut: (1) penyuluhan dengan pelatihan penyusunan formulasi ransum sapi pesisir dengan bahan baku lokal yang ada, (2) mengenalkan ke masyarakat pengawetan hijauan dengan metode ensilase, (3) mengenalkan ke masyarakat pengolahan jerami padi dengan cara amoniasi.

\section{PEMBAHASAN}

Kegiatan pemberdayaan masyarakat ini dilakukan dengan melibatkan mahasiswa kkn yang sedang kkn tematik hibah dikti. Mereka yang terpilih telah melakukan pembekalan terlebih dahulu di kampus tentang iptek yang akan dilakukan di lokasi kkn nantinya. Setelah mereka diseleksi disusun jadwal untuk pembekalan program kerja agar mereka dapat menjalankannya dengan baik di lokasi KKN nantinya.

Beberapa program yang akan dilakukan adalah 1). Sosialisasi ke masyarakat dengan membawa quisioner yang salah satu temanya adalah identifikasi sapi pesisir, 2) penyusunan formulasi ransum, 3) amoniasi jerami padi, 4) pembuatan silase ransum komplit dan 5) budidaya hijauan unggul.

\section{Sosialisasi dan Identifikasi Sapi Pesisir}

Sosialisasi ke masyarakat dengan membawa quisioner yang salah satunya berisikan tentang identifikasi sapi pesisir. Sosialisasi dilakukan oleh para mahasiswa, dimana dari 30 orang mahasiswa dibagi atas 2 jorong, dan setiap jorong sebanyak 3-4 orang mahasiswa bergerak turun ke masyarakat. Sosialisasi ini dilakukan selama seminggu dan dilakukan secara acak dari rumah ke rumah dengan memprioritaskan masyarakat yang punya sapi pesisir.

Sosialisasi dilakukan ke masyarakat sekaligus mendata peternak yang memelihara sapi pesisir. Sebanyak 80 orang quisioner yang didata maka diperoleh sekitar 28 orang yang mata pencaharian utamanya beternak dan selebihnya adalah nelayan dan petani. Dari data yang diperoleh terdapat sekitar 16 orang yang memelihara sapi pesisir yang lainnya memelihara unggas dan kambing. Sebanyak lebih kurang 60 ekor sapi pesisir yang dipelihara dengan perincian 23 ekor jantan, 26 ekor betina dan 11 ekor pedet.

Umumnya status peternak dalam memelihara sapi tersebut adalah sekitar 9 orang milik sendiri, 6 orang perseduaan dan 1 milik pemerintah. Jumlah berapa kali induk sapi tersebut beranak didapatkan sekitar 5 peternak yang sapimya beranak $>4$ kali, selanjutnya yang beranak 3 kali ada 2 peternak dan yang beranak 2 kali ada 2 peternak juga.

Kebanyakan peternak sudah mulai membuat kandang untuk sapi dan sebagian sudah disediakan tempat pakan, tetapi kebanyakan belum mempunyai drainase yang baik atau belum menyediakan tempat 
penampungan feses. Pakan yang diberikan pada umumnya rumput lapang dan belum banyak yang menanam rumput unggul seperti rumput gajah. Pemberian pakan dalam bentuk konsentrat belum banyak juga, dan konsentrat yang diberikan pada umumnya adalah dedak.

Hampir sebagian dari peternak tersebut melepaskan sapinya untuk mencari pakan sendiri dan sebagian mencarikan pakan untuk ternaknya. Sapi yang dilepaskan hanya sebagian yang dilepas di lahan milik sendiri dan yang lainnya dilepas di lahan milik masyarakat. Kebanyakan peternak tersebut belum banyak mendapatkan penyuluhan tentang upaya beternak atau masalah pakan.

Hampir semua dari peternak yang didata yang jadi masalah utama dalam beternak bagi mereka adalah masalah dalam pakan. Permasalahan dalam pakan adalah pakan susah didapatkan, tidak adanya iptek dalam penyediaan pakan dan pemberian pakan tidak sesuai dengan kebutuhan ternak.

Sosialisasi yang dilakukan oleh mahasiswa dilapangan dan respon dari masyarakat. Masyarakat sangat menanggapi dengan positif yang dilakukan oleh mahasiswa tersebut, dengan adanya sosialisasi dimana si mahasiswa datang langsung ke rumah warga sehingga terjalin hubungan saling mengenal antara mahasiswa dan masyarakat. Keuntungan bagi masyarakat adalah mereka dapat mengenal dan melihat sikap mahasiswa yang sopan dan santun, bagi mahasiswa tentu bisa belajar bagaimana hidup dilingkungan yang berbeda dan memahami karakter masyarakat. Quisioner yang disampaikan disamping masalah umum seperti biodata, masalah peternakan tentu yang menjadi utama untuk dapat mengetahui serta mengidentifikasi peternakan sapi pesisir di nagari taratak kecamatan sutera yang dahulunya merupakan daerah sentra sapi pesisir.

Dari responden didapatkan ada juga peternak yang tidak suka dimintai keterangan tentang data sapi mereka karena trauma dengan tidak adanya bantuan dari pemerintah. Selanjutnya ada sapi disana tetapi bukan punya warga taratak tetapi nagari tetangga disebelahnya. Dari masalah sapi dan pakan didapatkan berkurangnya jumlah peternak dan populasi sapi disebabakan karena pakan. Kesulitan mendapatkan pakan, malas untuk menyabit pakan setiap hari, tidak adanya lahan penggembalaan serta belum dimanfaatkan jerami padi sebagai pakan ternak. Sosialisasi mahasiswa terhadap masyarakat tersebut dapat dilihat pada Gambar 1.

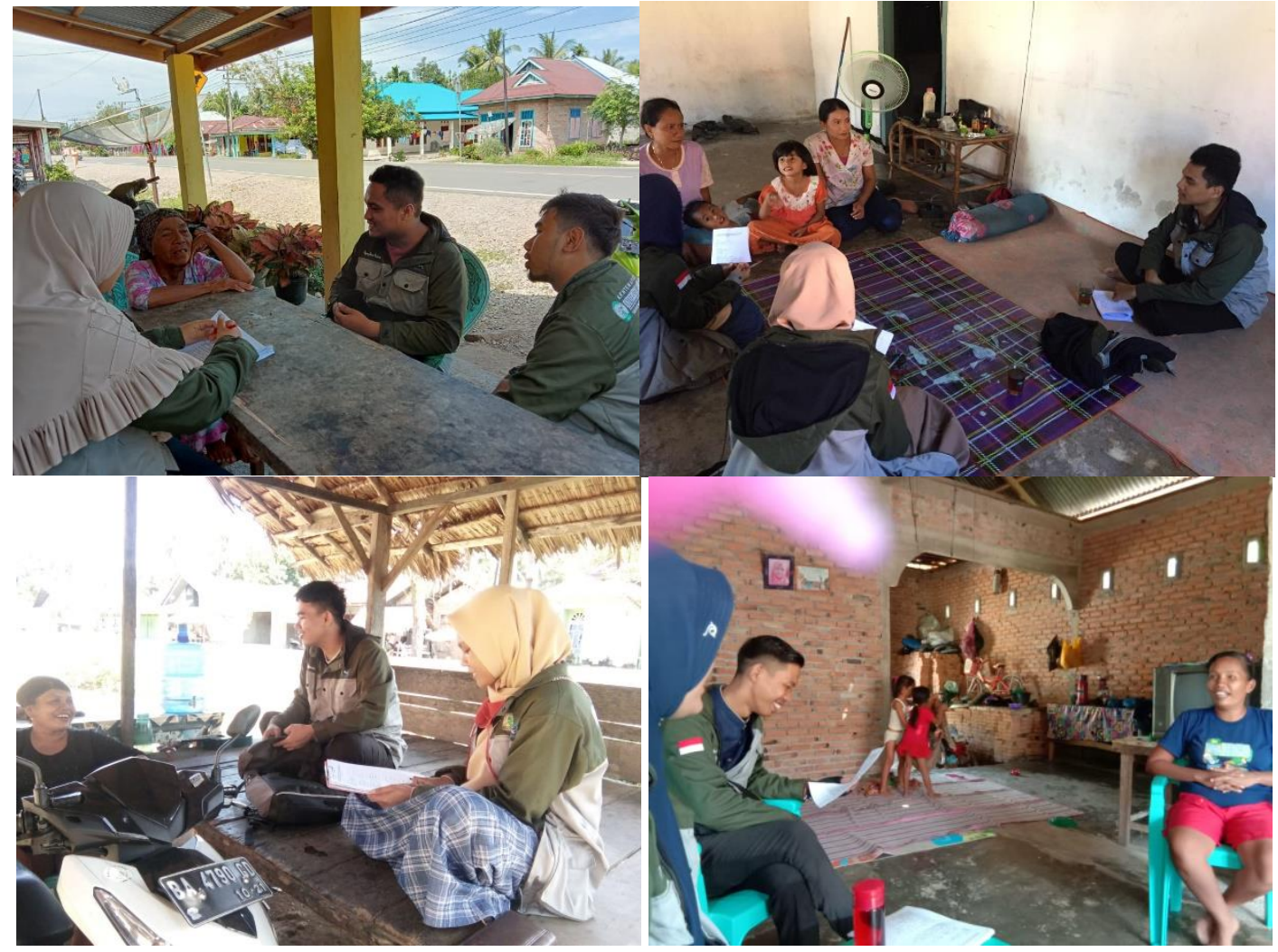

Gambar 1. Sosialisasi ke masyarakat

\section{Formulasi ransum sapi pesisir}

Dari kondisi dilapangan terlihat kurangnya pengetahuan masyarakat tentang pakan. Masyarakat tidak mengetahui jenis dan jumlah pakan yang dikonsumsi oleh ternak. Hal ini disebabkan karena ternak dilepaskan dan mengkonsumsi apa yang bisa di makan di lapangan, kalaupun ada yang dikandangkan akan tetapi peternak 
tidak menimbang makanan yang diberikan apakah sesuai dengan kebutuhan ternak tersebut. Berdasarkan hal tersebut perlu dibantu peternak tersebut untuk memberikan ransum sapi pesisir sesuai dengan kebutuhannya.

Bantuan yang dapat diberikan kepada peternak tersebut adalah dengan cara membuatkan formulasi ransum berdasarkan kondisi yang ada di lapangan. Formulasi ransum disusun dengan memanfaatkan sumber bahan pakan yang ada dilapangan. Ada 2 macam formulasi ransum yang ditawarkan yaitu 1) formulasi ransum dengan memanfaatkan jerami padi amoniasi dan yang ke 2) formulasi ransum dalam bentuk silase ransum komplit.

Formulasi ransum telah dibuat dan disajikan juga dalam bentuk leaflet (Gambar 2) sehingga masyarakat bisa membacanya dan mempraktekannya. Mahasiswa telah melakukan penyuluhan untuk itu dan tanggapan masyarakat sangat antusias sekali.
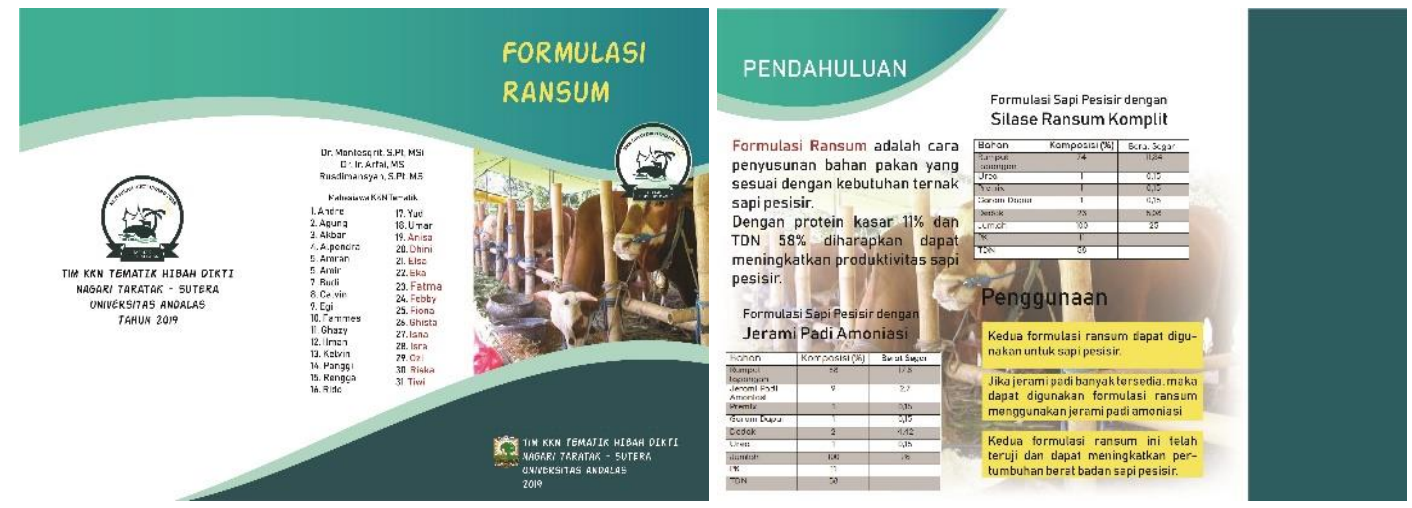

Gambar 2. Leaflet formulasi ransum

\section{Amoniasi jerami padi.}

Kebanyakan peternak belum memanfaatkan jerami padi sebagai bahan pakan sapi pesisir, mereka beranggapan jerami padi tidak bisa untuk sapi dan kebanyakan jerami padi tersebut dibakar. Memang betul kalau jerami padi saja diberikan keternak memang kecernaannya rendah, sedikit jerami itu yang dicerna di dalam saluran pencernaan. Hal ini disebabkan karena kandungan lignoselulosa yang ada didalamnya, dimana lignin dan selulosa berikatan kuat yang tidak bisa enzim yang ada dalam pencernaan sapi tersebut untuk mencernanya sehingga tidak tercerna dengan baik.

Salah satu upaya yang dapat dilakukan adalah mengolah jerami padi tersebut sebelum diberikan ke ternak. Cara pengolahan yang dilakukan dapat secara kimia yaitu amoniasi dan biologis yaitu dengan fermentasi. Dengan cara amoniasi yaitu menggunakan urea sedangkan dengan cara fermentasi menggunakan campuran urea dan probiotik. Probiotik yang digunakan dapat berupa probion atau starbio yang diproduksi oleh Balitnak Bogor, akan tetapi produk tersebut sukar didapatkan di Nagari ini maka untuk itu pengolahan jerami digunakan dengan cara amoniasi.

Mahasiswa juga telah diberi pembekalan sebelum ke lapangan dan mereka telah melakukannya di kampus dan dilapangan mereka siap membagikan ilmunya ke masyarakat. Mereka juga telah menyiapkan leaflet yang diberikan ke masyarakat pada saat penyuluhan dan demo pembuatan. Dengan adanya leaflet tersebut peternak dapat mempraktekannya nanti setelah diberi demo oleh mahasiswa. Pembekalan yang dilakukan sebelum ke lapangan, leaflet amoniasi jerami padi dan penyuluhan dan demo yang dilakukan oleh mahasiswa di Nagari Taratak dapat dilihat pada Gambar 3. 

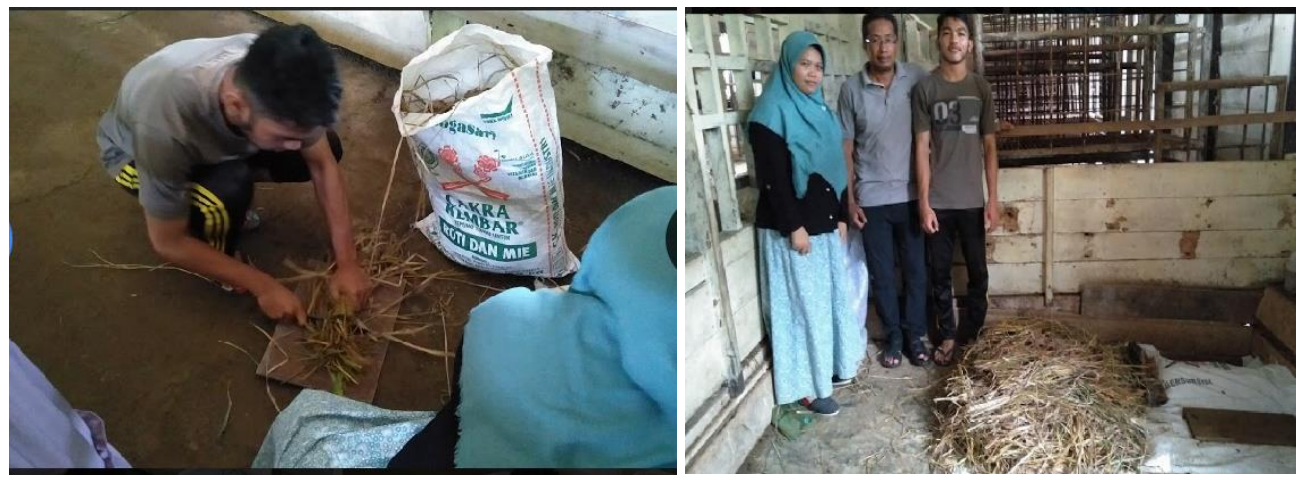

Gambar 3. Pembuatan jerami padi amoniasi

\section{Silase ransum komplit}

Salah satu yang membuat menurunnya minat beternak sapi pesisir adalah dalam penyediaan pakan. Bahan pakan ketersediaannya tidak terus menerus ada, cuaca yang berubah dimana dalam sehari hujan lebat atau panas terik sehingga membuat malas peternak dalam penyediaan pakannya. Keinginan peternak adalah pakan itu tersedia setiap saat dan peternak cukup memberikan sesuai dengan yang dibutuhkan oleh ternak.

Berdasarkan kondisi demikian tim kkn tematik hibah dikti terpanggil untuk meningkatkan produktivitas ternak sapi pesisir dengan memberdayakan masyarakat melalui program kkn ppm hibah dikti. Dalam program ini ketua tim kkn hibah dikti sudah merekrut beberapa mahasiswa yang akan melaksanakan program kkn pada semester ini untuk ikut bersama dengan tim, mahasiswa yang dipilih kebanyakan dari mahasiswa program studi peternakan dan separohnya lagi dari program studi yang lainnya. Mahasiswa-mahasiswa tersebut diberi pembekalan pembuatan silase ransum komplit yang berbasis produk pakan yang dominan disana.

Silase ransum komplit adalah ransum komplit yang diawetkan atau dijadikan ransum dengan proses ensilase. Ransum komplit adalah ransum yang disusun dari campuran hijauan dan konsentrat sekaligus diberikan ke ternak. Pada umumnya pemberian hijauan dan konsentrat tidak sekaligus, hijauan diberikan terlebih dahulu sesudah itu konsentrat atau sebaliknya. Ransum komplit yang diberikan disesuaikan dengan kebutuhan sapi pesisir yang telah dilakukan penyusunan formulasi ransumnya.

Dalam formulasi ransum disusun kandungan protein kasar dan TDN dari sapi pesisir tersebut adalah 11 dan $56 \%$. Bahan pakan yang digunakan untuk menyusun ransum tersebut adalah bahan pakan yang banyak tersedia disana yaitu rumput lapang sebagai hijauan dan untuk konsentrat digunakan dedak padi, urea, garam dan mineral. Sebelum dicobakan di lokasi kkn, mahasiswa juga sudah diberi pembekalan dan telah dipraktekan di kampus. Dokumentasi pembuatan silase ransum komplit, leaflaet yang sudah dibuat, penyuluhan dan demo pembuatan silase ransum komplit dapat dilihat pada Gambar 4 dan 5.
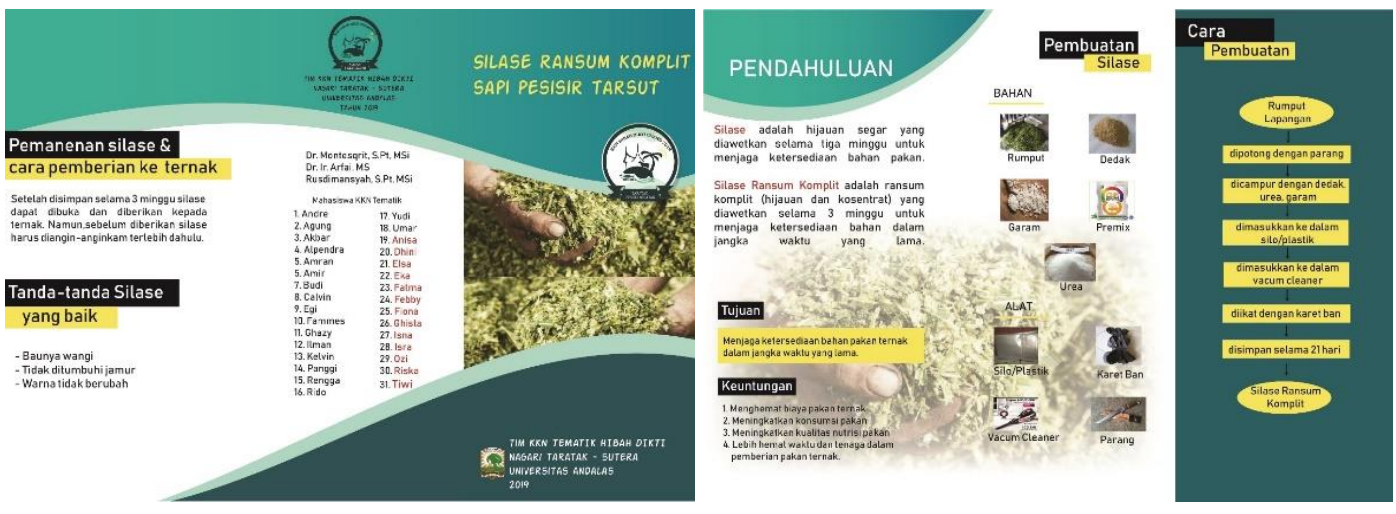

Gambar 4. leaflet pembuatan silase ransum komplit 


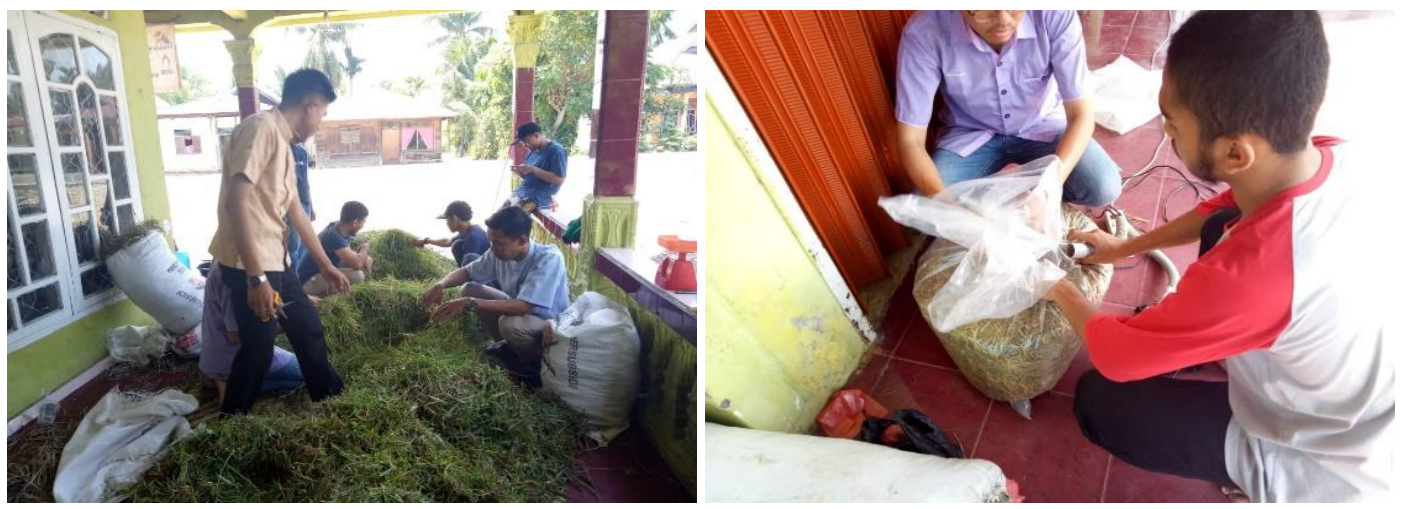

Gambar 5. Demo pembuatan silase ransum komplit

\section{Budidaya rumput gajah}

Hijauan yang banyak tersedia di nagari Taratak ini adalah rumput lapangan dan tidak terlihat adanya rumput unggul seperti rumput gajah. Rumput gajah adalah rumput yang mempunyai kandungan gizi yang baik, produktivitas tumbuhnya tinggi dan dapat tumbuh di nagari taratak. Berdasarkan hal tersebut dalam program pengabdian ini diberikan kepada peternak yang terpilih yang mau menyediakan lahannya untuk ditanami rumput gajah tersebut.

Rumput gajah yang diberikan adalah rumput gajah varitas taiwan yang diperoleh dari kampus fakultas Peternakan. Rumput gajah tersebut ditanam oleh mahasiswa bersama dengan masyarakat dengan terlebih dahulu diberi pembekalan tentang penananam hijauan unggul tersebut. Leaflet dan penanaman rumput gajah dapat dilihat pada Gambar 6 dan 7.
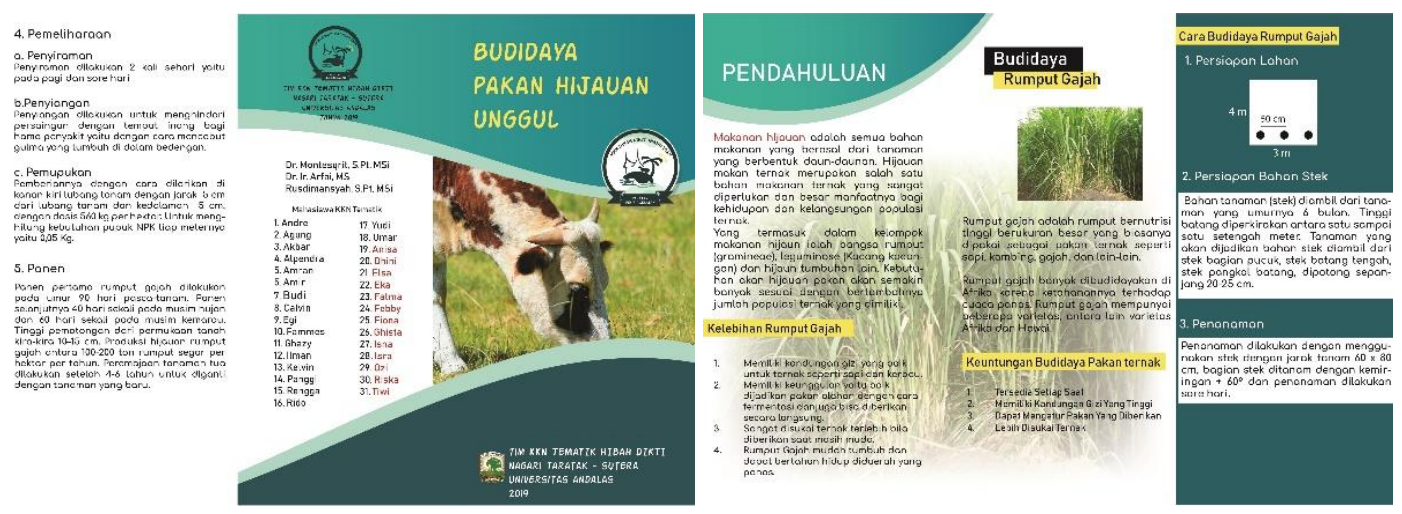

Gambar 6. Leaflet budidaya pakaan hijauan unggul
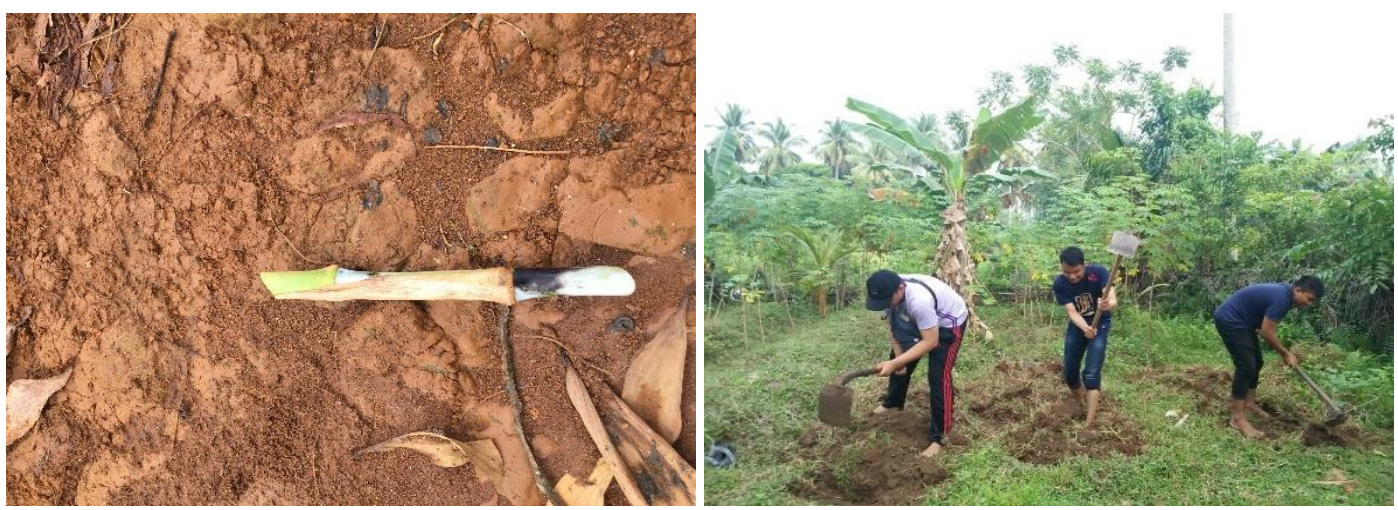

Gambar 7. bibit hijauan dan demo percontohan penanaman 


\section{KESIMPULAN}

Produktivitas sapi pesisir di nagari taratak berkurang dengan sedikitnya populasi sapi dan animo masyarakat untuk beternak berkurang karena keterbatasn pakan dan kurangnya pengetahuan masyarakat tentang pakan. Adanya mahasiswa kkn tematik dari unand yang menawarkan solusi permasalahan pakan sangat diminati oleh masyarakat, mereka dengan antusias yang tinggi datang menghadiri penyuluhan dan demo yang dilakukan oleh mahasiswa KKN.

Perlu dilakukan penelitian lebih lanjut untuk mengaplikasikan formulasi pakan yang ditawarkan yaitu berupa amoniasi jerami padi dan silase ransum komplit ke peternak disana.

\section{UCAPAN TERIMA KASIH}

Ucapan terima kasih diberikan kepada Simlitabmas Ristek Dikti yang telah mendanai program pengabdian masyarakat tahun 2019 ini dalam skim KKN PPM Tematik Hibah dikti.

\section{DAFTAR PUSTAKA}

Bamualim, A. M., \& R. B. Wirdahayati. 2006. Peran Teknologi dalam Pengembangan Ternak Lokal. Dalam Prosiding Seminar Nasional Peternakan (BPTP) Sumatera Barat.

Dipertahorbunnak Kabupaten Pesisir Selatan. 2012. Laporan Dinas pertanian, Hortikultural, Perkebunan dan Peternakan Kabupaten Pesisir Selatan.

Helmiati. 2016. Kawasan Perdesaaan Budidaya Sapi di Kabupaten Pesisir Selatan Provinsi Sumatera Barat. Pusat data dan informasi. Kemendes Pembangunan Daerah Tertingal dan Transmigrasi.

Wahyuni, R., \& R. A. Dewi. 2018. Teknologi Tepat Guna Mendukung Pengembangan Sapi Lokal Pesisir Sumatera Barat. Jurnal Litbang Pertanian 37(2): 12-23. 